\title{
The work process for the promotion of students with special needs integrated in the kindergartens of regular education: the case of israel
}

\begin{abstract}
Nava Bar, The work process for the promotion of students with special needs integrated in the kindergartens of regular education: the case of israel. Interdyscyplinarne Konteksty Pedagogiki Specjalnej, nr 17, Poznań 2017. Pp. 271-286. Adam Mickiewicz University Press. ISSN 2300-391X

The Special Education Law in Israel was legislated on July 12, 1988. The law determined precedence and advance preference for the placement of special needs students in the regular educational system over the special education system. In the spirit of the law, methodical and painstaking processes that arrange the work with special needs students in the educational system were determined. This article presents two work processes implemented in parallel in the regular kindergartens. The first work process is with students who have functional difficulties, before their definition and as prevention of their definition as students with special needs. The second process is the work process with the special needs students who are integrated in the regular kindergartens, intended to prevent their referral to frameworks of special education. These processes reflect the development that occurred in the importance ascribed in the educational system in Israel to careful and adjusted work with students who have difficulties and special needs and are integrated in the kindergartens of regular education. Alongside the described development, the article presents the challenges and the questions that the implementation of the processes poses.
\end{abstract}

KEY WORDS: kindergarten, students with functional difficulties, students with special needs, work process 


\section{Special Education in Israel}

The Israeli educational system was founded in the In the late 1980s, in a gradual process of implementation of the assimilation of the approach that emphasizes the rights of the students with special needs and their integration in one educational system with their peers members of the same age group ${ }^{1}$. As part of this approach, special attention has been given to the development of a continuum of educational frameworks based on the principle of the least restrictive environment (LRE) ${ }^{2}$. The continuum of frameworks is intended to provide an appropriate solution to the needs of the diverse population of students with special needs ${ }^{3}$. The assumption is that this population is diverse in terms of the severity of disabilities and in terms of the student's needs; therefore as the framework is more separate, the services given there to the student will be more comprehensive $^{4}$. The continuum of educational frameworks for students with special needs ranges in Israel from special education kindergartens from age three ${ }^{5}$ and special education schools till age twenty-one; special classes in the regular schools; and inclusion in regular kindergartens and in regular classes in schools of regular education. The inclusion framework operates according to the model

${ }^{1} \mathrm{G}$. Avissar, Inclusion and accessibility: Curriculum planning and implementation for students with disabilities, Mofet Institute, Tel Aviv, 2010; N. Bar, A. Kizel, On the continuum from mainstreaming to inclusion: The development of the approaches towards students with special needs and their expression in the educational frameworks in Israel, Interdisciplinary contexts of Special Pedagogy, 2016, 11, pp. 161-188; M. Marom, K. Bar-Simon Tov, A. Kron, P. Koren, Inclusion of special needs children in the regular educational system: A review of the literature, The Center for the Research of Social Policy in Israel Press, Jerusalem, 2006.

2 G. Avissar, A. Moshe, P. Licht, "These are basic democratic values": The perceptions of policy makers in the Ministry of Education with regard to inclusion, [in:] Inclusiveness: From theory to practice, eds S. Reiter, G. Avissar, AHVA Publishers, Haifa, 2013.

${ }^{3}$ H. Ronen, Inclusion: Issues and disputes, [in:] Inclusiveness: Learners with disabilities in education, eds S. Reiter, Y. Leyser, G. Avissar, AHVA Publishers, Haifa, 2007.

${ }^{4}$ N. Bar, A. Kizel, On the continuum from mainstreaming to inclusion.

5 The students with severe disabilities are referred to special education kindergartens from age three by the medical services in the community. 
of full inclusion, in which students with different functioning levels study in a shared scholastic space, having full partnership with the peer group. The guiding principle in the placement of the student with special needs into one of the frameworks is the placement into an environment that will limit the student's development the least according to the LRE principle 6 . In addition, the placement of the student with special needs into one of the frameworks is realized only after it has been found that the support and services given to the student in the framework in which he learned, based on the severity of the disability, do not allow to provide him with effective education?

A significant step in the development of special education in Israel was the legislation of the Special Education Law on July 12, $1988^{8}$. The Law determined precedence and advance preference of the regular educational system over the special education system, assuming that a student with special needs who will be integrated, as much as possible, in regular education will be ready for full integration in society outside of the areas of the educational system ${ }^{9}$. An example can be found in the statement published in the Circular of the general director of the Ministry of Education on June 2013:

One of the touchstones of the educational system in Israel is its ability and willingness to provide an appropriate educational-scholastic solution for the special needs of students who find it difficult to adjust in scholastic or social terms to the norms accepted in the regular education framework, and to avoid, to the extent possible, their referral to the special education frameworks ${ }^{10}$.

${ }^{6}$ P. Klein, V., Sobelman-Rozental, Together and alone: Integrating children with special needs into regular educational frameworks in the Early Childhood. Reches Publishers, Even Yehuda, 2000.

${ }^{7} \mathrm{H}$. Ronen, Inclusion: Issues and disputes.

8 The Special Education Law, 5748, State of Israel, 1988.

${ }_{9}^{9}$ M. Marom, K. Bar-Simon Tov, A. Kron, P. Koren, Inclusion of special needs children in the regular educational system; G. Avissar, Inclusion and accessibility; G. Avissar, A. Moshe, P. Licht, "These are basic democratic values".

${ }^{10}$ Circular of the Director General: The mainstreaming program in the regular education frameworks for dealing with students with special needs who learn in the regular 
In the spirit of the Special Education Law and the perception on which the law relies, methodical and painstaking processes that arrange the work with special needs students in the educational system were determined.

\section{The Work Processes with Students with Functional Difficulties in the Kindergarten}

The composition of the population in the kindergarten is heterogeneous (for the most part) and contains children whose characteristics, abilities, and difficulties are varied. In every kindergarten there are usually a few children who have difficulties. Their difficulties can arise from various sources (biological, environmental) and can be expressed in varying degrees of severity, ranging from temporary and transient difficulties to persistent difficulties. Some of them constitute a basis for deficiencies that will appear in a later stage $^{11}$. Studies indicate that there is a connection between developmental problems in early childhood and subsequent behavioral problems and social difficulties ${ }^{12}$. Two structured and systematic processes are held in parallel in the kindergarten in Israel for the treatment of students with difficulties aged three to six - the work process with students who have functional difficulties and the work process with the special needs students who are integrated in the regular kindergartens, in order to prevent their referral to the

classes and in the special education classes. Ministry of Education, Jerusalem, June 1, 2003, 10(b).

11 "Mabatim" (Looks), Guidance booklet for assessment and observation in kindergartens for the in-depth Familiarity of children. Ministry of Education, Jerusalem, 2016.

12 M.H. Cantell, T.P. Ahonen, M.M. Smyth, Clumsiness in adolescence: Educational, motor, and social outcomes of motordelay detected at 5 years. Adapted Physical Activity Quarterly, 1994, 11, pp. 115-129; A.J. Reynolds, J.A. Temple, D.L. Robertson, E.A. Mann, Long-term effects of an early childhood intervention on educational achievement and juvenile arrest: A 15-year follow-up of low-income children in public schools. JAMA. 2001, 285(18), pp. 2339-2346. 
framework of special education. The processes reflect the efforts invested in the identification and support of students with functional difficulties, out of the understanding that the period of childhood is critical in the child's development ${ }^{13}$. Many studies emphasize the importance of the first years in the child's life as a significant period of development, in which he develops the basis for various skills, shaping his personality and especially his cognitive development ${ }^{14}$. Moreover, studies indicate that early identification and intervention in cases of developmental delays and developmental difficulties may affect the development and learning of children in the early childhood $^{15}$, especially in the first and two years after completion of the intervention program ${ }^{16}$. They may reduce future problems in skills and functioning in various areas such as cognitive functioning, social skills, and academic achievement ${ }^{17}$. Gitanjali, Scott-Little, and Clifford (2000) emphasize that early identification and adjusted interventions at this age, for those who need it, may enable the prevention of the emergence of social-emotional difficulties, the prevention of the creation of gaps in relation to peers; the prevention or

${ }^{13}$ L.M. Anderson, C. Shinn, M.T. Fullilove, S.C. Scrimshaw, J.E. Fielding, J. Normand, V.G. Carande-Keulis, The effectiveness of early childhood development programs. American Journal of Preventive Medicine, 2003, 24(3), pp. 32-46; P. Klein, V. Sobelman-Rozental, Together and alone.

${ }^{14}$ S.W. Bijou, Development in the preschool years: A functional analysis, American Psychologist, Aug 1975, 30(8), pp. 829-837; L.A. Karoly, M.R. Kilburn, J.S. Cannon, Early childhood interventions: Proven results, future promise, Rand Corporation, California, 2005.

${ }^{15}$ M.B. Bruder, Early childhood intervention: A promise to children and families for their future, Exceptional Children, 2010, 76(3), 339-355; M.J. Guralnik, Effectiveness of early intervention for vulnerable children: A developmental perspective. American Journal on Mental Retardation, 1998, 102(4), pp. 319-345.

${ }^{16}$ J. Leak, G.J. Duncan, W. Li, K. Magnuson, H. Schindler, H. Yoshikawa, Is timing everything? How early childhood education program impacts vary by starting age, program duration and time since the end of the program. Presented at the association for policy analysis and management meetings, Boston, MA, November 4-6, 2010.

${ }^{17}$ G. Camilli, S. Vargas, S. Ryan, W.S. Barnett, Metaanalysis of the effects of early education interventions on cognitive and social development. Teachers College Record, 2010, 112(3), pp. 579-620. 
reduction of the severity of difficulties in functioning; the realization of abilities that are not expressed spontaneously ${ }^{18}$ and the increase, for some of the students, of the chances of remaining in the regular education.

The starting point of the work processes with students who have difficulties is the view of every student as an individual, and it is expressed in the identification of the student's difficulties and the response to his special needs through the construction and implementation of a personal educational intervention program. In the implementation of the work process with students who have functional difficulties, all the educational staff in the kindergarten is partners, under the leadership of the kindergarten teacher, with the support of the kindergarten psychologist, and with a regular dialogue with the student's parents. The process begins with a functional assessment conducted by the kindergarten teacher for all the kindergarten students aged three to four, at the beginning of the school year. The assessment is performed according to the program of the Ministry of Education called 'Mabatim' (Looks)19, with each student in an individual manner. The goal of the assessment is to identify the students' difficulties in the different areas of performance - cognitive, lingual, motor, sensory, social, and emotional. On the basis of the assessment performed, students with functional difficulties who need support adjusted to their needs are identified. The initial identification of each student's abilities is essential in any individual work plan ${ }^{20}$. Based on the assessment, personal intervention programs are built by the kindergarten teacher for the students with functional difficulties. Main goals are defined and the ways of work of the educational staff with the students are determined in

18 S. Gitanjali, C. Scott-Little, R.M. Clifford, Readiness for school: A survey of state policies and definitions. Early Childhood Research and Practice, 2000, 2(2), pp. 1-18; M.J. Guralnik, Effectiveness of early intervention for vulnerable children: A developmental perspective. American Journal on Mental Retardation, 1998, 102(4), pp. 319-345.

19 "Mabatim" (Looks), Guidance booklet for assessment and observation in kindergartens.

20 S. Bagnato, Authentic assessment for early childhood intervention best practices, Guilford Press, New York, 2007. 
the individual, group, or full kindergarten class setting. The intervention program includes various kinds of interventions, for example: using visual means for a student who has difficulty in the understanding of the language; supporting the student who has difficulty in moving from activity to activity; choosing a suitable composition for group work, and more. In addition to the interventions provided by the kindergarten teacher, in cases where additional intervention is needed, the children will be referred to the diagnostic-therapeutic systems in the community. A significant component of the intervention program is its activation in the child's natural environment ${ }^{21}$.

In the middle of the year, processes of follow up and control are conducted for the examination of the student's progress according to the intervention program, and changes are made as necessary, so as to provide an adjusted solution to the student and to promote the student in the kindergarten framework. In this stage, decision is made about the students, in the Community Inclusion Committee, subject to their parents' consent and with their participation in the meeting 22 . The committee will determine the entitlement of the student in the coming school year for support in the kindergarten framework from the resources of special education including support from special education staff members. The Community Inclusion Committee operates according to the Special Education Law, under the leadership of the Ministry of Education kindergartens supervisor. The Committee decisions are based on an acceptable assessment performed for the student by an educational psychologist or developmental doctor who defines the student as a student with special needs. The Inclusion Committee discusses only stu-

${ }^{21}$ M.B. Bruder, Early childhood intervention; R.M. Vilaseca, M.J. Del Rio, Language acquisition by children with Down syndrome: A naturalistic approach to assisting language acquisition. Child Language Teaching and Therapy, 2004, 20. 163-180.

22 The Special Education Law 5762-2002 (Amendment No. 7), State of Israel, 2002; Circular of the Director General: The implementation of the Special Education Law: Institutional mainstreaming committee, placement committee sitting for appeals against the mainstreaming committee, placement committee, and appeals committee, Ministry of Education, Jerusalem, January 1, 2014, 15(a). 


\section{dents for whom the regular educational framework has realized all of its possible educational interventions with them ${ }^{23}$.}

Table 1. The work processes with students with functional difficulties in the kindergarten led by the homeroom kindergarten teacher

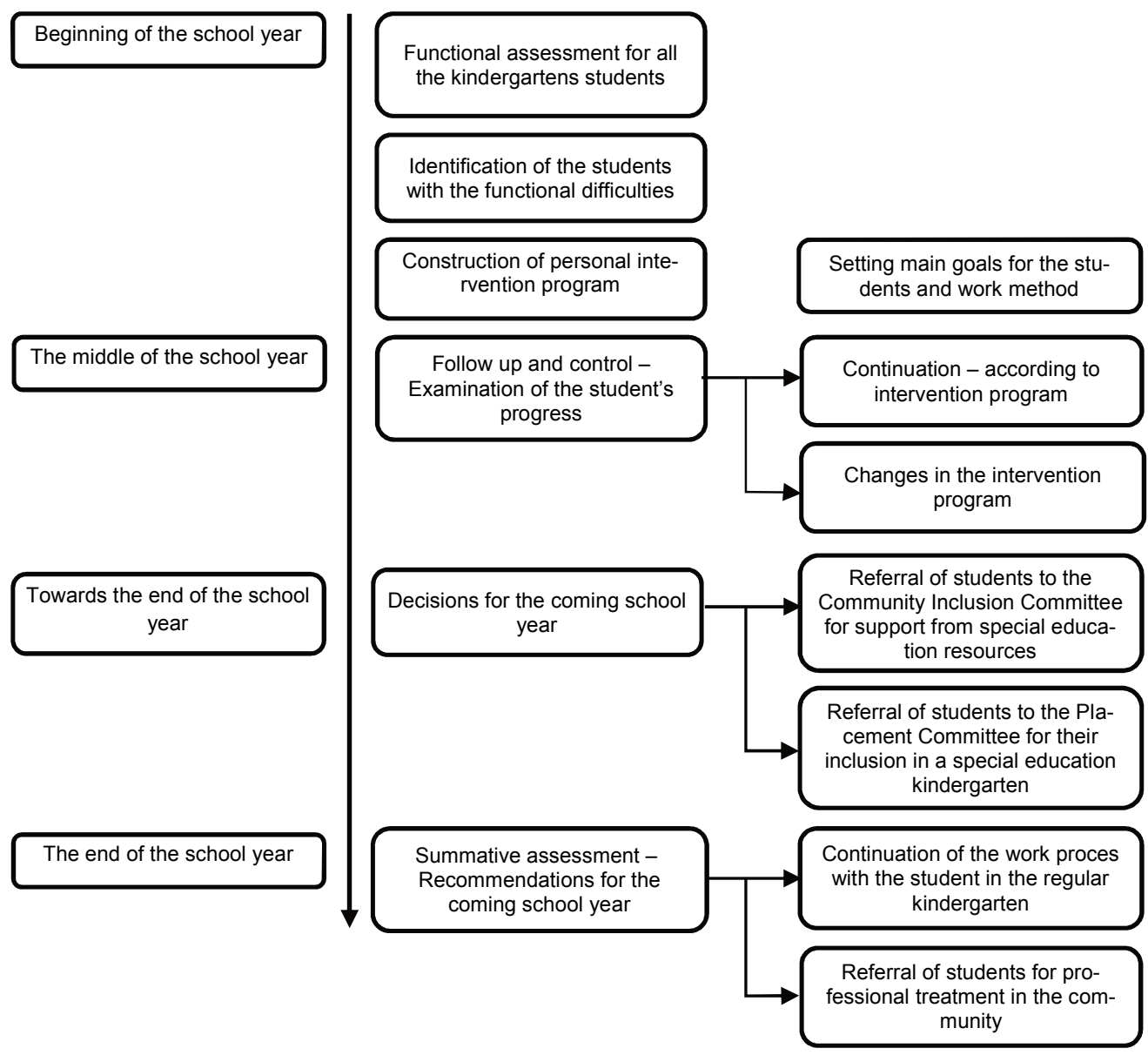

${ }^{23}$ Circular of the Director General: The implementation of the Special Education Law, January 1, 2014, 15(a). 
Towards the end of the year, a number of decisions are taken, with the involvement of the parents, about the kindergarten students for whom a personal intervention program was prepared during the year. One decision is made by the Community Inclusion Committee that convenes and determines which students will be entitled to support from the resources of special education in the coming school year in the regular kindergarten ${ }^{24}$. A second decision is made about a very few students, who have especially prominent difficulties, about their referral to the Placement Committee for their inclusion in a special education kindergarten in the coming school year. Such a decision will be made only after the examination that all educational interventions with the students in the regular education framework were realized completely ${ }^{25}$. At the end of the school year, a summative assessment is performed for the students, in accordance with the goals set for them in the intervention program. In this stage, recommendations are given for the continuation of work with the students in the regular kindergarten in the coming school year, as well as recommendations for the referral of students for treatment from different professional factors in the community, such as paramedical therapists. Table 1 describes the presented work processes with students with functional difficulties in the kindergarten led by the homeroom kindergarten teacher.

\section{The Work Processes with Students with Special Needs in the Kindergarten}

Two models are applied in Israel for the inclusion of students from kindergartens that are defined as having special needs by the Community Inclusion Committee (called in Israel 'inclusion students'). The common model is the inclusion of students with mild disabilities in the regular kindergartens and the support of them by

\footnotetext{
24 Ibidem.

25 Ibidem.
} 
the special education kindergarten teacher, two to three hours per week, in an individualized manner or in small learning groups, inside or outside of the kindergarten class. The main teaching of these students continues to be held by the kindergarten teacher who was not trained for special education. For the most part, the special education kindergarten teacher works with the student outside of the homeroom class. The aspiration is to work with the student in his natural environment, in the space of the kindergarten, with members of the age group, and also to enable the modeling for the kindergarten teacher of adjusted work with the student who has special needs. The second model, which is not common for budgetary reasons, is the 'inclusive kindergartens' in which a number of students with special needs, generally up to eight, study along with 'regular' students. In these kindergartens there are two teachers: the homeroom kindergarten teacher and the special education kindergarten teacher. The teaching curriculum is determined by both teachers. Some of the kindergarten activities are together with all the children and in some of the activities the students with special needs learn separately with the special education kindergarten teacher. The goal is to integrate the students with the special needs in all the kindergarten class activities $^{26}$. A few students, integrated into the kindergarten that operates according to both models, receive treatment totaling one weekly hour from an occupational therapist, speech therapist, or therapist in the emotional area. Studies indicate that there is a direct connection between the emotional-social functioning and the child's effective adaptation, his sense of well-being, scholastic success, and the development of a proper relationship between the teacher and the student in the future ${ }^{27}$. These studies highlight the importance of emotional treatment for the kindergarten students who need it.

${ }^{26}$ P. Klein, V. Sobelman-Rozental, Together and alone.

${ }^{27}$ C. Blair, school readiness integrating cognition and emotion in a neurobiological conceptualization of children's functioning at school entry. American Psychologist, February 2002, 57(2), pp. 111-127; P.A. Graziano, R.D. Reavis, S.P. Keane, S.D. Calkins, The role of emotion regulation in children's early academic success. Journal of School Psychology, 2007, 45, pp. 3-19. 
The work process with the special needs students, in each of the models, is conducted in parallel to the process led by the kindergarten teacher with the students with functional difficulties. The work of the special education kindergarten teacher is based on the collection of comprehensive data on every student at the start of the year; a conversation for acquaintanceship with the parents; observations of the student in the kindergarten at different times and during different activities that enable expression of the varied behavior of the students in daily routines according to their abilities and difficulties 28 ; and a personal examination for the student in the different areas of functioning. All these lead to the construction of an individual educational program, as required under the Special Education $\mathrm{Law}^{29}$, with the participation of the kindergarten teacher, the kindergarten psychologist, and the student's parents. During the construction of an individual educational program the goals of the work with the student are determined. The special education kindergarten teacher holds a continuous relationship with the kindergarten teacher and with the paramedical therapists from the community, if there are, for the creation of continuity with the treatment held outside of the kindergarten space. In the middle of the year, formative assessment is held to examine the progress of the special needs student ${ }^{30}$. For the few who are intended to go to the school in the coming school year, decisions are made about their referral to the Placement Committee for the examination of the possibility of their placement in the special education class in the regular school or their placement in the special education school ${ }^{31}$. At the end of the year, a process of summative assessment is held for the examination of the student's progress. Accordingly, recommendations for the continuation are made, to end or to continue the support of the

28 S. Bagnato, Authentic assessment for early childhood intervention.

${ }^{29}$ The Special Education Law 5762-2002 (Amendment No. 7), State of Israel, 2002.

${ }^{30}$ Circular of the Director General: The implementation of the Special Education Law, January 1, 2014, 15(a).

${ }^{31}$ Circular of the Director General: The implementation of the Special Education Law, January 1, 2014, 15(a). 
Table 2. The work processes with students with special needs in the kindergarten

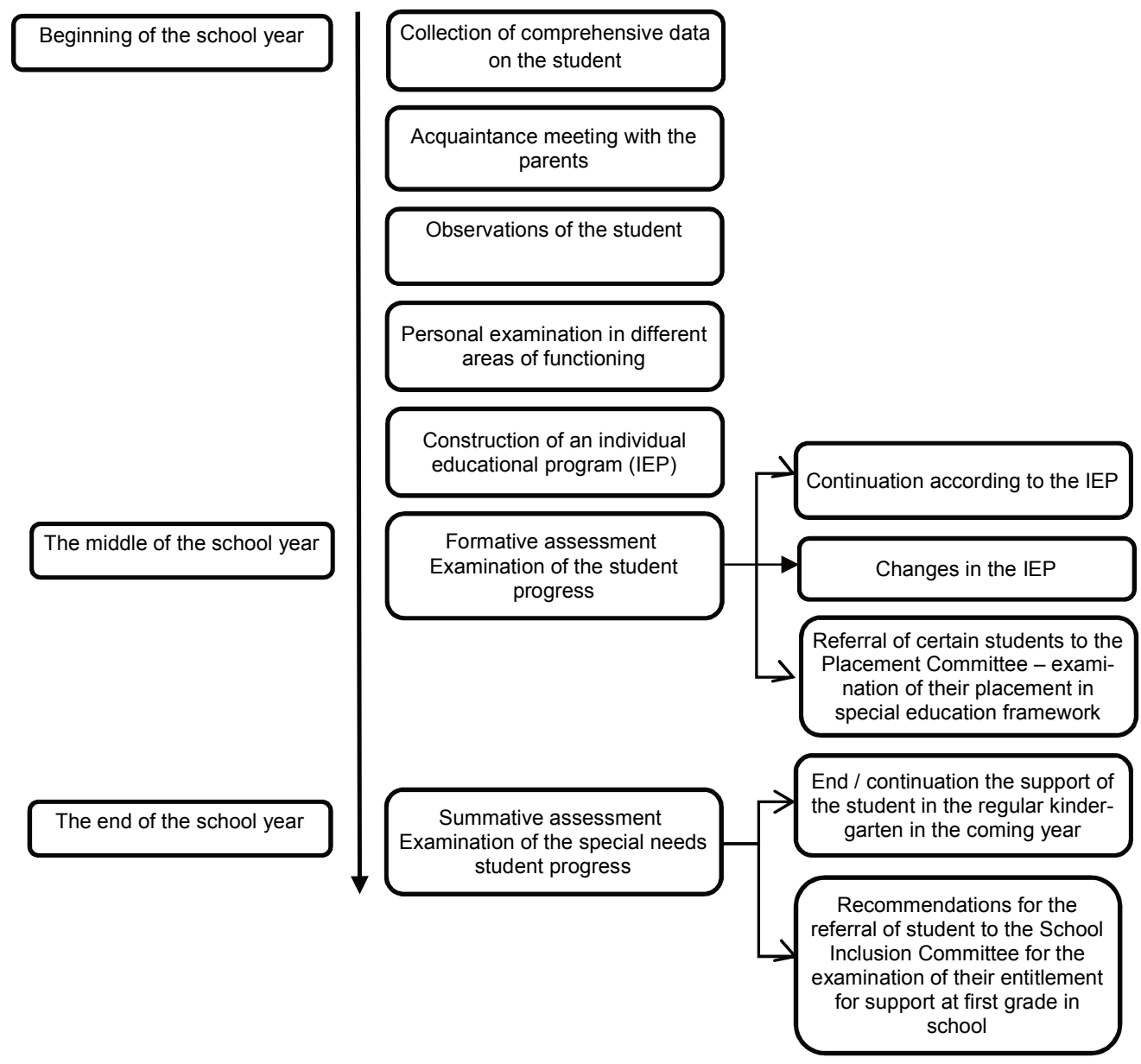

student from the resources of special education in the coming school year in the kindergarten ${ }^{32}$. For those who are intended to go to school, there are recommendations for the absorbing schools for

32 Circular of the Director General: The implementation of the Special Education Law, January 1, 2014, 15(a). 
the referral of certain students to the School Inclusion Committee at the start of the first grade to obtain entitlement for support from the resources of special education in the school. Throughout the entire process described, the student's progress is painstakingly examined, with a dynamic view of the program built for him, and necessary changes are introduced in it according to the need, and with the parents' involvement in their child's progress and the decisions made on his matter. Table 2 describes the presented work processes with students with special needs in the kindergarten.

\section{Summary - Developments, Challenges and questions}

The described process reflects the development that occurred in the importance ascribed in the educational system in Israel to careful and adjusted work with students who have difficulties and special needs and are integrated in the kindergartens of regular education. The determination that the student will not be entitled to support from the special education services unless it is proved that all interventions with him in the framework of regular education were realized indicates the caution adopted by the educational system in the definition of the child as having special needs. It also indicates the transfer of the responsibility to the kindergarten teacher for the early stage identification of students with difficulties, the construction of adjustment programs for them, and the implementation of these programs. The emphasis placed today on the involvement of the entire staff and the parents in the implementation of the personal programs creates shared responsibility and focuses the work of all on the adjusted goals determined for work with the student. Alongside these perceptual developments, the kindergarten staff copes with a number of challenges. The limited special education resources make it difficult to provide appropriate support for students with special needs who are integrated in the kindergartens, and the special education kindergarten teacher finds herself working a limited number of weekly hours with her special needs stu- 
dents. Moreover, support from the special education kindergarten teacher is given to students with the lowest functioning in the kindergarten, thus delaying the advancement of other students who have difficulties. In addition, the main support provided to the students is of the type of teaching, while there are students who need support in other or additional areas, such as the motor and emotional-social areas, for whom there is mostly no answer, so the gap in development of some of the students may increase. Likewise, alongside the perceptual developments and methodical processes implemented in the kindergartens of regular education in Israel, a number of questions are addressed. Does the kindergarten teacher perceive herself as responsible for the special needs student integrated in the kindergarten? Does the kindergarten teacher have the knowledge and instruments for the advancement of the special need students and, are they sufficient for the prevention of the students' referral to the framework of special education?

\section{Bibliography}

Anderson L.M., Shinn C., Fullilove M.T., Scrimshaw S.C., Fielding J.E., Normand J., Carande-Keulis V.G., The effectiveness of early childhood development programs. American Journal of Preventive Medicine, 2003, 24(3).

Avissar G., Inclusion and accessibility: Curriculum planning and implementation for students with disabilities, Mofet Institute, Tel Aviv, 2010. [in Hebrew]

Avissar G., Moshe A., Licht P., "These are basic democratic values": The perceptions of policy makers in the Ministry of Education with regard to inclusion, [in:] Inclusiveness: From theory to practice, eds S. Reiter, G. Avissar, AHVA Publishers, Haifa, 2013. [in Hebrew]

Bagnato S., Authentic assessment for early childhood intervention best practices, Guilford Press, New York, 2007.

Bar N., Kizel A., On the continuum from mainstreaming to inclusion: The development of the approaches towards students with special needs and their expression in the educational frameworks in Israel. Interdisciplinary contexts of Special Pedagogy (Interdyscyplinarne Konteksty Pedagogiki Specjalnej), 2016, 11.

Bijou S.W., Development in the preschool years: A functional analysis, American Psychologist, Aug 1975, 30(8). 
Blair C., School readiness integrating cognition and emotion in a neurobiological conceptualization of children's functioning at school entry. American Psychologist, February 2002, 57(2).

Bruder M.B., Early childhood intervention: A promise to children and families for their future, Exceptional Children, 2010, 76(3).

Camilli G., Vargas S., Ryan S., Barnett W.S., Metaanalysis of the effects of early education interventions on cognitive and social development. Teachers College Record, 2010, 112(3).

Cantell M.H., Ahonen T.P., Smyth M.M., Clumsiness in adolescence: Educational, motor, and social outcomes of motor delay detected at 5 years. Adapted Physical Activity Quarterly, 1994, 11.

Circular of the Director General: The mainstreaming program in the regular education frameworks for dealing with students with special needs who learn in the regular classes and in the special education classes. Ministry of Education, Jerusalem, June 1, 2003, 10(b). [in Hebrew]

Circular of the Director General: The implementation of the Special Education Law: Institutional mainstreaming committee, placement committee sitting for appeals against the mainstreaming committee, placement committee, and appeals committee, Ministry of Education, Jerusalem, January 1, 2014, 15(a). [in Hebrew]

Gitanjali S., Scott-Little C., Clifford R.M., Readiness for school: A survey of state policies and definitions. Early Childhood Research and Practice, 2000, 2(2).

Graziano P.A., Reavis R.D., Keane S.P., Calkins S.D., The role of emotion regulation in children's early academic success. Journal of School Psychology, 2007, 45.

Guralnik M.J., Second generation research in the field of early intervention, [In:] The effectiveness of early intervention, ed. M.J. Guralnik, Paul H. Brookes Publishing Co., Baltimore, 1997.

Guralnik M.J., Effectiveness of early intervention for vulnerable children: A developmental perspective. American Journal on Mental Retardation, 1998, 102(4).

Karoly L.A., Kilburn M.R., Cannon J.S., Early childhood interventions: Proven results, future promise, Rand Corporation, California, 2005.

Klein P., Sobelman-Rozental V., Together and alone: Integrating children with special needs into regular educational frameworks in the Early Childhood. Reches Publishers, Even Yehuda, 2000. [in Hebrew]

Leak J., Duncan G.J., Li W., Magnuson K., Schindler H., Yoshikawa H., Is timing everything? How early childhood education program impacts vary by starting age, program duration and time since the end of the program. Presented at the association for policy analysis and management meetings, Boston, MA, November 4-6, 2010.

"Mabatim" (Looks), Guidance booklet for assessment and observation in kindergartens for the in-depth Familiarity of children. Ministry of Education, Jerusalem, 2016. [in Hebrew] 
Marom M., Bar-Simon Tov K., Kron A., Koren P., Inclusion of special needs children in the regular educational system: A review of the literature, The Center for the Research of Social Policy in Israel Press, Jerusalem, 2006. [in Hebrew]

Reynolds A.J., Temple J.A., Robertson D.L., Mann E.A., Long-term effects of an early childhood intervention on educational achievement and juvenile arrest: A 15-year follow-up of low-income children in public schools. JAMA. 2001, 285(18).

Ronen H., Inclusion: Issues and disputes, [in:] Inclusiveness: Learners with disabilities in education, eds S. Reiter, Y. Leyser, G. Avissar, AHVA Publishers, Haifa, 2007. [in Hebrew]

The Special Education Law, 5748, State of Israel, 1988. [in Hebrew]

The Special Education Law 5762-2002 (Amendment No. 7), State of Israel, 2002. [in Hebrew]

Vilaseca R.M., Del Rio M.J., Language acquisition by children with Down syndrome: A naturalistic approach to assisting language acquisition. Child Language Teaching and Therapy, 2004, 20. 